\title{
SUSTAINABLE MOBILITY AND URBAN SPACE QUALITY: THE CASE OF GRANADA, SPAIN
}

\author{
A.L. GRINDLAY ${ }^{1}$, G. OCHOA-COVARRUBIAS ${ }^{2}$ \& C. LIZÁRRAGA ${ }^{3}$ \\ ${ }^{1}$ Department of Urban and Regional Planning, University of Granada, Spain* \\ ${ }^{2}$ Habitat and Urban Development Department, ITESO, Jesuit University of Guadalajara, Mexico ${ }^{\dagger}$ \\ ${ }^{3}$ Applied Economics Department, Faculty of Business and Economics, University of Granada, Spain
}

\begin{abstract}
The urban environment and the quality of the urban spaces are greatly affected by different forms of mobility, from the extremely impactful mass use of private vehicles to the 'soft' pedestrian walkways and cycle paths, and also through the several modes of public transport. In this paper we first explore the different urban impacts of these forms of mobility and the interaction between the urban system and the transportation system, and we then analyse the relationship of factors promoting urban quality in accordance with literature on urban design. Next, an analysis of the street's cross section is made, as the quality of this space is inextricably linked to its grade of sustainable mobility. The results of this study are contrasted with the experience within Granada's Metropolitan area, which has a high level of private vehicular use, for example its heavy congestion coupled with severe environmental pollution. A new light rail system (LRT) has been developed, with major urban renewal along its track. The LRT has the particularity of having varied cross sections, whereby the improvement in quality of urban space along them can be evaluated. The high-quality urban spaces are those with virtually no vehicular access whatsoever, providing a completely pedestrianized area, such as in the traditional urban road crossing axes in the outlying districts, which are now almost completely free from vehicles and are more greatly accessible to people. As a result of current social distancing required by the COVID-19 pandemic, urban space, which can be configured in a very adaptable way, is changing in many cities including Granada, giving more space in their streets to sustainable mobility modes and, therefore, indirectly increasing their quality and longevity. The changes carried out in Granada reveal a requirement for the promotion of improvement in urban spaces and sustainable mobility on a metropolitan scale, since the LRT is not enough if it is not accompanied by other urban development and mobility integrated measures.

Keywords: Granada, LRT, public transport system, sustainable mobility, urban quality, urban sustainability.
\end{abstract}

\section{INTRODUCTION: MOBILITY AND URBAN SPACE}

Considering the complexity of the urban space, the relationship and interactions between the transportation and mobility systems are clearly perceived. Transportation has a major impact, as observed by Vuchic [1], "not only on the physical form of cities but on their liveability the quality of their natural and man-made environments". Generally, these interactions have been explained largely in terms of land use and changes in patterns of activity, transformed by

"ORCID: http://orcid.org/0000-0001-5176-0550.

ORCID: http://orcid.org/0000-0002-2864-6634.

ORCID: http://orcid.org/0000-0002-3221-6178. 
the extended accessibility created by the transport infrastructures, and their long-term impact $[2,3]$. The purpose of this work is to analyse the nature of the symbiotic relationships [4], exploring the role of the public transport systems, sustainable mobility and the quality, not only of the urban public spaces [5] but also of the urban space in general. The metropolitan area of Granada will be assessed according to these considerations.

Varying impacts of different forms of mobility within the urban space are greatly diversified. Spatially, the concentrated accessibility of public transport systems gives a cluster of activities around their stops affecting land use, increasing land rents and promoting higher density developments [2], whilst private vehicle infrastructures cause them to spread over the suburban territory [1]. From an environmental perspective, the increase in private vehicular use and the subsequent traffic density is widely and traditionally documented as a fundamental element in the deterioration of living conditions and the exacerbation of urban environmental problems [6-8]. On the contrary, public transport systems are, by their very nature, more sustainable than private vehicular-based transport systems, as a result of their social, economic and environmental performance [9-11].

The 2020 spring 'lockdown' due to the COVID-19 pandemic demonstrated the great impact on air quality within our cities caused by such heavy traffic and that improved air purity can be achieved with lower traffic circulation density [12]. Pollution and congestion levels have since returned to their higher states, or even greater in some cases, as people are opting to use private motorized vehicles instead of public transport due to a fear of infection, and pollution/ congestion levels have reverted to an unsustainable trend [13]. All cities have experienced equivalent COVID-19-instigated challenges, forcing the adoption of similar measures and models to address the new situation in order to guarantee safe and sustainable post-pandemic urban areas [12-14].

Sustainable mobility, resulting from a greater participation of sustainable transport modes in the mobility modal split, plays a central role in the quality of urban areas $[8,9,11]$. In addition, it is broadly recognized that sustainable mobility is promoted by sustainable urban forms. Urban plans should create 'contained' and compact urban configurations, with diverse uses in close proximity, reducing travel demand and fostering the use of local services and facilities. As a consequence, high densities provide enough population to support public transport services creating greater focus of population and employment and encouraging walking and cycling $[9,15,16]$. A high investment in sustainable transport solutions, such as public transport infrastructures and services, will unquestionably have a large impact on the urban space, the quality of life of the population and the betterment of locations and environments within cities [1,9,16-18]. The strong links identified between sustainable urban mobility and urban sustainability can be demonstrated through the promotion of walking and cycling and the support of a well-designed public transport system, offering frequent, fast and direct services, and the location of transit stations, employment opportunities, homes and amenities all within walking distance of each other, or within close proximity [9], to ensure that sustainable modes of transport are more attractive $[19,20]$.

In order to analyse the nature of the symbiotic relationships between public transport systems, sustainable mobility and the quality of the urban space in the metropolitan area of Granada, this work is organized into three more sections. In the next section we examine the role of sustainable mobility and public transport systems in the quality of urban spaces with consideration to the literature on urban design concepts. Pursuant to these observations, different sustainable mobility levels will be determined for various street configurations, and they will be considered in the context of Granada's metropolitan area and its public transport 
system, lately improved with a light rail transit (LRT) line. Lastly a modest increase in urban quality is reported due to implementation of the LRT.

\section{SUSTAINABLE MOBILITY AND URBAN QUALITY}

\subsection{Urban sustainable model and urban sustainable mobility}

The need to restrict private indiscriminate vehicular access in urban areas to ensure their environmental quality was early established by Buchanan's "environmental capacity areas" [7]. According to Parfect and Power, the first negative indicator for urban quality was the "excessive impact of vehicular/parking requirements upon the urban scene" [8], nowadays we should also consider the increased use of electric vehicles and their similar impact. There have been many examples of high-quality modern pedestrian-oriented areas been developed utilizing space previously allotted to private vehicles [21-23]. Thus, these traditional high "environmental capacity areas" [7] have been recognized as "a major regulating tool for urban quality" [8], and have been extensively implemented. An up-to-date example in Spain is Barcelona's recent superblock model, where its urban structure is being re-organized "to discourage cut-through traffic and promote multiple uses of street space" [24]. Similarly, there are urban development proposals to implement a more pedestrian focused paradigm based on the proximity model, demonstrated in the "15-minute city" proposal, recently experienced in Paris [25]. Furthermore, vehicle restrictions are also vital, not only to reduce pollution emissions and enhance the quality of urban space but, in addition, to ensure the success of public transit systems [1]. It is widely recognized that their greatest benefits will be accomplished by the integration of transport and urban or land use planning $[2,9,16]$. The private vehicle restriction approach must be complemented taking into consideration the role of public transportation in sustainable mobility. In particular, public transport has an effect on all dimensions of urban sustainability, changing the form of a city, and is linked to energy efficiency and social cohesion, promoting the sustainable urban model, in other words, a compact city in its morphology, complex in its organization, metabolically efficient and socially cohesive [26]. As has been demonstrated in Oslo, higher social cohesion is associated with public transport accessibility [27]. So, in this relationship between the sustainability of the urban and transportation/mobility systems to attain urban liveability, the quality of the public transport systems is essential to promote walking and cycling and favouring sustainable transport modes to be competitive with motorized private transport. This is shown in the next table according to an assessment model on their attributes and characteristics [28], where mobility and services are highlighted. The proposed "15-minute city" concept, in addition to considering 'density', 'proximity' and 'diversity', that are capitalized in the table, also includes 'digitalization', in line with the present "smart city" paradigm for post-pandemic cities [25]. These should be adopted in new urban developments or reforms and the negatives associated with excessive density such as pollution and congestion should also be avoided (Table 1).

\subsection{Sustainable transport modes and urban quality}

Keeping in mind these reciprocal interactions between mobility and urban space, it is worth exploring in what respect sustainable transport modes, and particularly public transport systems, affect the urban environment and the quality of the urban space, given its recognized significant capacity for 'placemaking' [4,5,29]. 


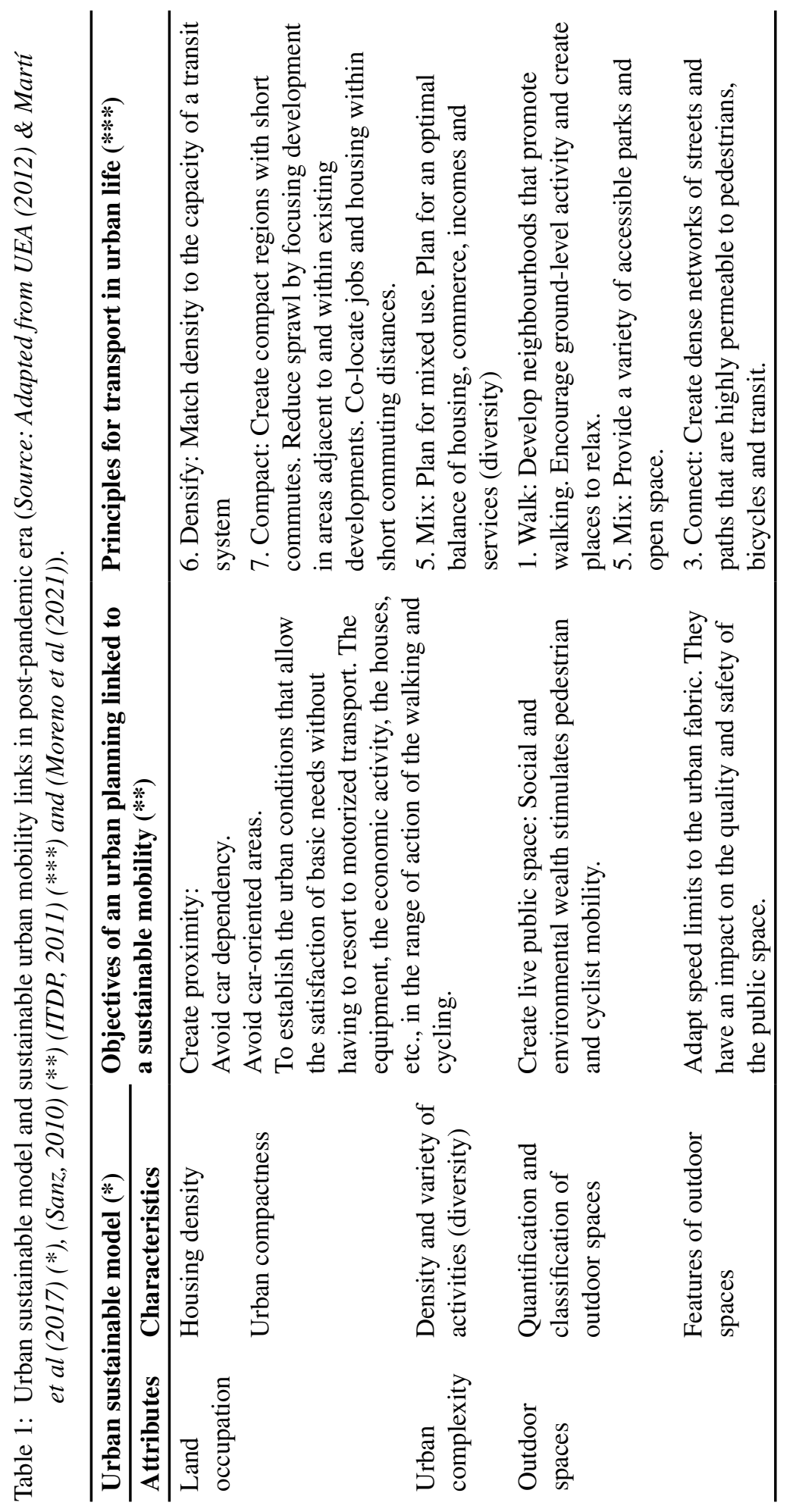




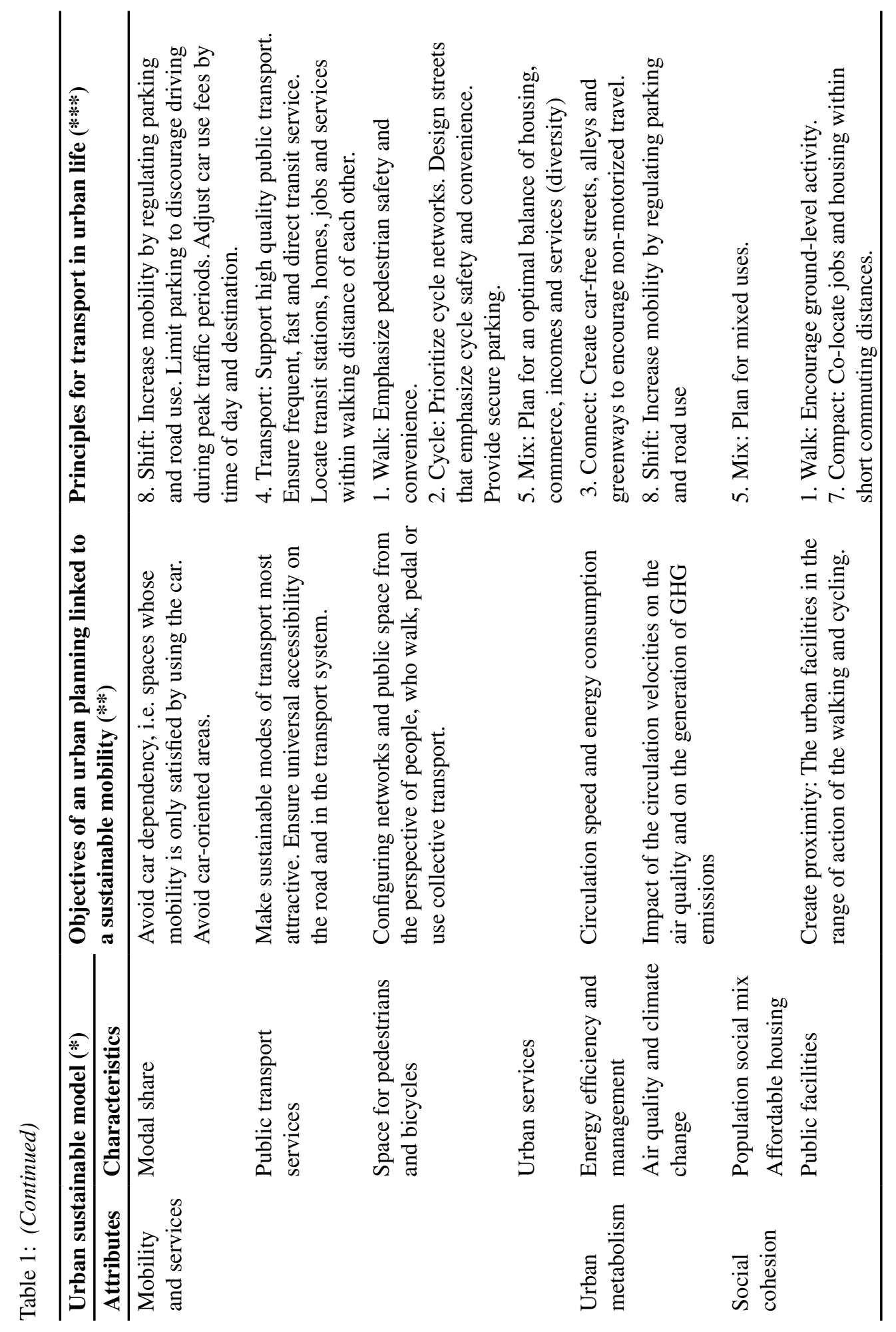


Essentially, sustainable transport modes are those alternatives to private vehicles in urban mobility such as walking, cycling, personal light electric vehicles and public transportation - especially electric powered - under global and continuous upgrade and development [9,11,30,31]. The increasing participation of theses modes in the urban mobility will help to promote high-quality accessibility and contribute to the high-quality environment of cities [9].

The issue of 'quality' in urban areas as linked to mobility has been prominent in the disciplines of urban planning and design since the seminal work of Jacobs (1961) [32], and it was also reinforced by the sustainability paradigm from the 1990s [8,32]. Thus, urban quality has become a significant feature in achieving urban sustainability by means of the coordination of urban and public mobility policies. Due to its essential complexity, there is a broad consensus on the multi-dimensional character of its nature, and that it cannot be easily measured or fully identified as it is dependent on both tangible and intangible elements [8,32-34]. However, an approximation is possible by considering several component factors, such as, those summarized by Parfect and Power: "finance, including provision for maintenance; amenity, i.e. attractiveness for people and uses; traffic and parking, including provision for pedestrian and access; security/safety for people, uses, property, etc.; and order/organization i.e. clarity of purpose, whether applying to single or mixed uses" [8]. In addition, indicators of urban quality have been extensively discussed in urban design literature as a measurement of the tangible and intangible elements with respect to data on several dimensions of cities, with particular regard to walkability, such as "imageability, enclosure, human scale, transparency and complexity", as proposed by Ewing and Handy [35]. Furthermore, digital technologies and digital mapping have enabled detailed spatial analysis [36-38].

Urban quality may be associated with urban design concepts such as urbanity and vitality, as most distinctive characteristics of cities, and also those promoting urban sustainability, and they have been widely discussed. With respect to 'urbanity', according to Montgomery [39], there are three essential urban dimensions linked to this: "activity, image and form". As he explained, these could be achieved as a result of some detailed principles. Moreover, some basic conditions should be considered for achieving urban 'vitality', as have been listed and described by Jacobs as: "concentration, diversity, contact opportunity, need for aged buildings, accessibility and distance to border vacuums" [32]. As has been proved again in Oslo, neighbourhood density and the varied use of urban space are positive predictors of urban vitality [27]. Certainly, they are related to the referred principles and have been charted in Barcelona highlighting the areas of greatest vitality [40].

Thus, sustainable urban mobility is strongly associated with a street's vitality and liveability $[20,36,41]$, as is currently recommended in the people-oriented sustainability framework of the UN New Urban Agenda [42].

Sustainable transport modes promote and/or increase urbanity and vitality and, therefore, an improvement in urban quality. The most basic mode, walking, is clearly linked to urban quality [8] and pedestrian access has also been used as a measure of it [43,44]. On the other hand, bicycles and more recently, personal light electric vehicles, will need their own space to avoid conflicts with pedestrians or share the street space with other vehicles, whilst generating positive transformations in the public space of cities $[45,46]$. With respect to public transport systems, focusing on the indicated urban design's principles and conditions permits the comprehension of how they promote urbanity, vitality in cities and in the clear correlation between them, as can be seen in Table 2 . 


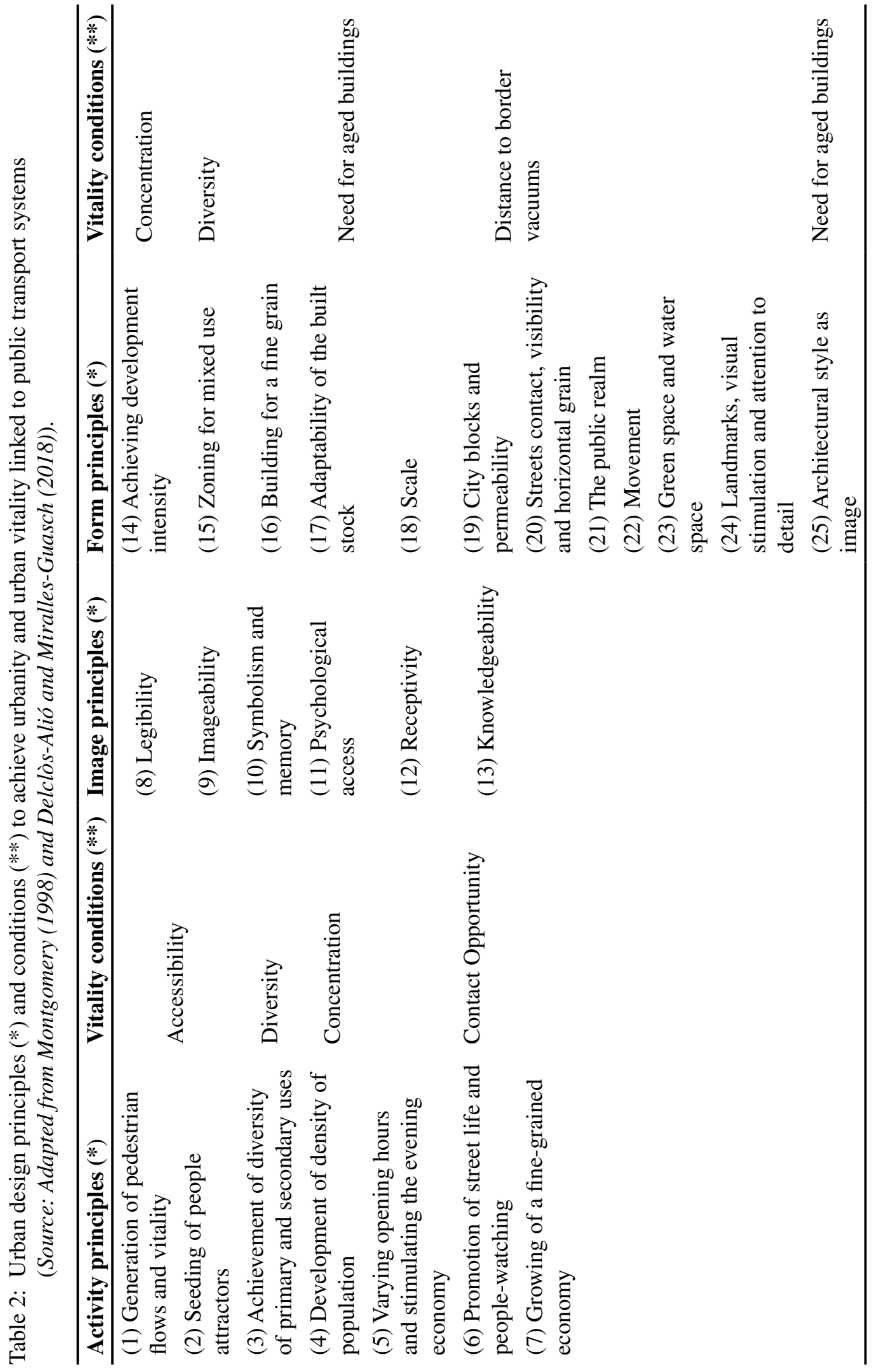


Thus, as has been previously explained [5], these systems increase urban accessibility, activity and contact opportunities, requiring and promoting population and employment opportunities [2], and are therefore linked to the related vitality conditions, and activity principles. On the other hand, physical transformation of the urban space is associated with modern transport developments, improving sustainable mobility-oriented areas. This links to the form and image principles and characteristics of the public realm (see Table 2). The spatial efficiency of public transportation in the occupancy of urban space with respect to other transportation modes, especially cars [1], is one of the most important elements of their urban impact. Therefore, its development has led to multiple examples of urban space recovery, as has been previously indicated. Though, showing different levels of recognized success, the potential for urban public transport to transform cities will be different for each situation depending on several factors, as indicated by Pflieger et al., "of reproduction and dependency: technical, morphological, political and institutional" [47].

\subsection{LRT systems creating high-quality urban areas and sustainable mobility levels}

Among the different forms of public transportation, rail-based modes have been revealed to have a greater and longer lasting impact on urban areas, due mainly to their heavier physical characteristics and permanence [48], particularly when in comparison to bus-based transport systems such as the Bus Rapid Transit [29].

Indeed, as has been evidenced in an increasing number of cities all over the world [49], rail transit systems, and particularly LRT, have proven to be the more beneficial public transport mode, enhancing human orientation within cities and having a major impact on them. Their compatibility with pedestrian zones and other people-oriented areas is especially relevant $[1,8]$. This is demonstrated particularly well in the case of the French tramways and their urban redevelopment [50], which have been created with a specific place-image and identity purpose in mind [29]. They have been an important reference for other countries, particularly Spain and their LRT developments.

The relationship between light rail developments and city boosterism as a place-making process has been analysed by Ferbrache and Knowles [29] in order to develop an objective interpretation of terms regarding quality, liveability and attractiveness of cities. In addition, the new LRT system's modern image has become a distinctive feature for a city's prestige, signifying 'progress and development' and promoting the perception of what a city should be. Their place-making effect is best achieved through the integration of these transport infrastructures with urban planning and land-use, as previously stated [4,16]. This has been successfully carried out by city planners and transport developers, "marrying together both engineering and environmental/physical appearance considerations" [8], and favouring proximity dynamics [51]. This strategy "towards achieving sustainability principles and more liveable cities", has transformed urban areas and improved urban 'image and quality' from street level to full scale city development [29].

To this end, contemporary LRT systems have mostly been developed through both reurbanization and the promotion of the public realm along the transit corridor [50]. Their construction has consisted of a complete urbanization renewal from beginning to end. Highquality physical environments are developed with pedestrian-friendly areas, improving the appeal of the streetscape, making it attractive not only to the transit passengers but also to the population in general. This urban renewal and the new high-capacity mode of public transport, reducing private car use and promoting sustainable transport modes, are the main 
urban effects directly linked to urban quality. Among these attributes it should be highlighted that limiting the operational speed of LRT systems makes them fully-compatible with pedestrianized and pedestrian-oriented areas, creating high-quality urban areas in accordance with the sustainability dimensions, as indicated in Table 3 [1,2,11,16,29,50].

By performing spatial analysis through mapped indicators similar to those utilized in Barcelona [40] and in other cities [38], we are able to assess the quality of the urban space. In addition, the zonal quality considerations of the urban spaces can be examined according to the linear dimension of the streets, as previously developed with the comprehensive "link \& place" methodology for street planning and design [52]. This attention to the streets' cross section could also be considered with respect to the conformity between the urban sustainability and the sustainable mobility models, which has already been discussed. Therefore, as a first simple approximation, the public space quality of the streets can be considered relative to the level of sustainable mobility that is taking place in their space. In this respect, an easy analysis of the sustainable mobility level of the streets according to their existing cross sections is presented with reference to the long-established level of service strata [53]. Subsequently, the proportion of sustainable mobility areas can be easily assessed, with respect to

Table 3: LRT and high-quality urban areas according to sustainability dimensions (Source: Adapted from Miller et al. (2016), Vuchic (2017) and Bertolini (2017)).

\begin{tabular}{|c|c|c|c|}
\hline \multicolumn{4}{|c|}{ Sustainability dimensions } \\
\hline Spatial & Environmental & Social & Economic \\
\hline $\begin{array}{l}\text { Efficient and reduced } \\
\text { space occupation }\end{array}$ & $\begin{array}{l}\text { No atmospheric } \\
\text { contamination }\end{array}$ & $\begin{array}{l}\text { Community } \\
\text { cohesion }\end{array}$ & $\begin{array}{l}\text { Increased economic } \\
\text { efficiency }\end{array}$ \\
\hline $\begin{array}{l}\text { Barrier effect limited } \\
\text { according to frequency }\end{array}$ & Noise reduction & $\begin{array}{l}\text { Community } \\
\text { livability }\end{array}$ & $\begin{array}{l}\text { Contributions to } \\
\text { economic activity }\end{array}$ \\
\hline Fully-accessible & $\begin{array}{l}\text { Decrease pollution } \\
\text { land-water }\end{array}$ & Safety and health & Reduced user cost \\
\hline Quality urban design & $\begin{array}{l}\text { Decrease in energy } \\
\text { use }\end{array}$ & $\begin{array}{l}\text { Aesthetics and } \\
\text { modern image }\end{array}$ & $\begin{array}{l}\text { Improved intermodal } \\
\text { system }\end{array}$ \\
\hline
\end{tabular}

Table 4: Levels of sustainable mobility of proposed street cross-sections analysis (Source: Own research).

\begin{tabular}{lll}
\hline Sustainable mobility level & $\begin{array}{l}\text { Sustainable mobility area } \\
\text { (SMA) }(\%)\end{array}$ & $\begin{array}{l}\text { Unsustainable mobility area } \\
\text { (UMA) }(\%)\end{array}$ \\
\hline A & 100 & 0 \\
B & $80-100$ & $20-0$ \\
C & $60-80$ & $40-20$ \\
D & $40-60$ & $60-40$ \\
E & $20-40$ & $80-60$ \\
F & $0-20$ & $100-80$ \\
\hline
\end{tabular}


the 'soft' modes areas for pedestrians and cycles, including the public transport areas and, in contrast, the proportion of the space given to motorized vehicles as an unsustainable mobility area (Table 4). In the next section we will examine how this methodology will be applied to the metropolitan area of Granada.

\section{THE CASE OF GRANADA'S METROPOLITAN AREA}

Granada is a provincial capital of the southern region of Andalusia (Spain) surrounded by more than thirty municipalities, shaping an urban agglomeration of around half a million inhabitants (Fig. 1). The historical tram system, developed in the beginning of last century, disappeared during the 1970s due to the growth of motorization. Since then, Granada has had a bus-dominated public transport system but the majority of its daily mobility consists of private motorized transport $(79 \%)$. The use of public transport scarcely makes up $8 \%$ of

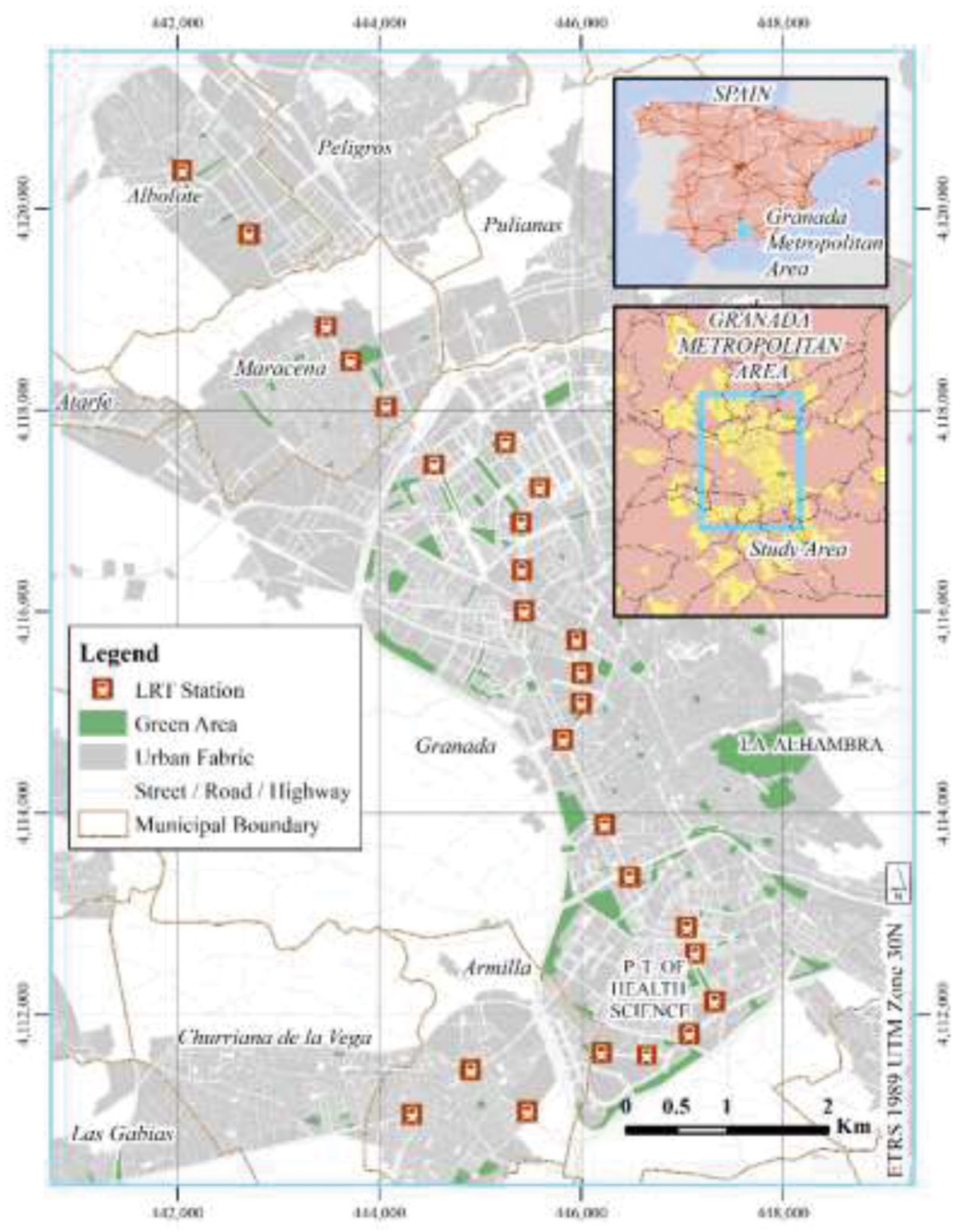

Figure 1: Granada's metropolitan area location and its recent LRT (Source: Own research). 
journeys, and travel by foot or bicycle just 13\% [6]. This has resulted in high levels of congestion and severe pollution problems, similar to Spain's most populated areas of Madrid and Barcelona. Despite having less traffic Granada's problems are exacerbated by its geographical and climatic conditions [54].

The Andalusian regional government mobility policy has created metropolitan transport authorities to coordinate public transport systems and new LRT lines in their main urban areas [55]. Metropolitan and urban sustainable mobility plans were also drafted to solve their mobility problems [6].

The construction and operation of Granada's new metropolitan LRT (completed in 2017), with reference to Section one, has resulted in a great improvement in the quality of the existing public transport system. As a modern rail-based mode, the LRT favours intramodality with the connection of bus and railway stations and the rearrangement of the existing bus routes to serve it. Prior to the current pandemic, it had succeeded in reaching the expected numbers of passengers, increasing pedestrian mobility and reducing private vehicles dependence in the areas it serves [5]. Referring to the previously mentioned French experiences, it has been developed with consideration for its high urban transformational potential, giving a substantial urban renewal along its corridor and increasing the accessible pedestrian area by more than one hundred thousand square meters. Viewing this with regard to the second Section, it clearly contributes, as stated by the referred principles, to increased urbanity and vitality conditions. Despite the high urbanization quality for pedestrians along the route of the LRT, some areas are still more oriented towards motorized mobility. The higher quality sections are those with no private vehicular access whatsoever, providing a pedestrianized area completely free of vehicles in the traditional urban road crossing axis in the town of Armilla and along the university central campus. Although some potential opportunities to integrate the transport infrastructure with urban planning and land-use have neither been considered or achieved [56].

However, the contribution of private vehicles and the resultant congestion and pollution levels continues to remain high. This is in large part due to the fact that the urban and metropolitan sustainable mobility plans have not been entirely fulfilled, despite improvements in the public transport system. In fact, only low-cost measures, such as traffic signalling and traffic restriction in central areas, have been carried out [57]. The sustainable urban mobility plan proposed with our advice an ambitious neighbourhood spatial design, based on the multifunctionality of the public space, favouring proximity mobility [58], in line with the previously mentioned traditional "environmental capacity areas" and "15-minutes city" [7,25]. This would involve substantial transformation of the urban space, including the adaptation of the pavement and street furniture, and the recovery of a large surface area for public space totalling approximately $150 \mathrm{Ha}$.

Evaluating the sustainable mobility level of the metropolitan streets by analysing their existing cross sections, or inversely the predominance of motorized vehicles in the urban space (both by field work and virtually, through Google Street View), almost all metropolitan streets and avenues are of conventional urban design and are oriented towards motorized vehicle access. The majority of sections, according to the proposed scale outlined in Table 4, have moderate to high traffic space $(\mathrm{C}-\mathrm{E})$. The exceptions to this are the commercial and historical areas, urban parks, and the referred LRT corridor, which achieve A-B levels of sustainable mobility. Most of the streets were designed several decades ago with a high inertia in the physical urban transformation due to limited municipal resources, however a few central urban areas have been renovated in recent decades, thanks primarily to European funding. 
As can be seen in Fig. 2, there is a greater majority of vehicular access in the area, and type A sections, indicating plenty of sustainable mobility areas, and therefore urban spaces of high-quality are very limited. At the other end of the scale, sections E and F designate fully motorized vehicle-oriented areas, such as motorways, where pedestrian or bicycle access is excluded.

On the other hand, urban space can be configured in a very adaptable way, and it can be changed relatively quickly by restricting access to private vehicles simply with new street signalling, as has been shown in the cited examples [21,23]. Currently, social distancing required by the COVID-19 pandemic has meant that many cities are giving more space in their streets to sustainable mobility modes and creating low-traffic neighbourhoods [14,25], and Granada is no exception. Street areas for pedestrians, bicycles and other personal mobility modes have been increased [58] some streets will now change to level $\mathrm{C}$ and, therefore,

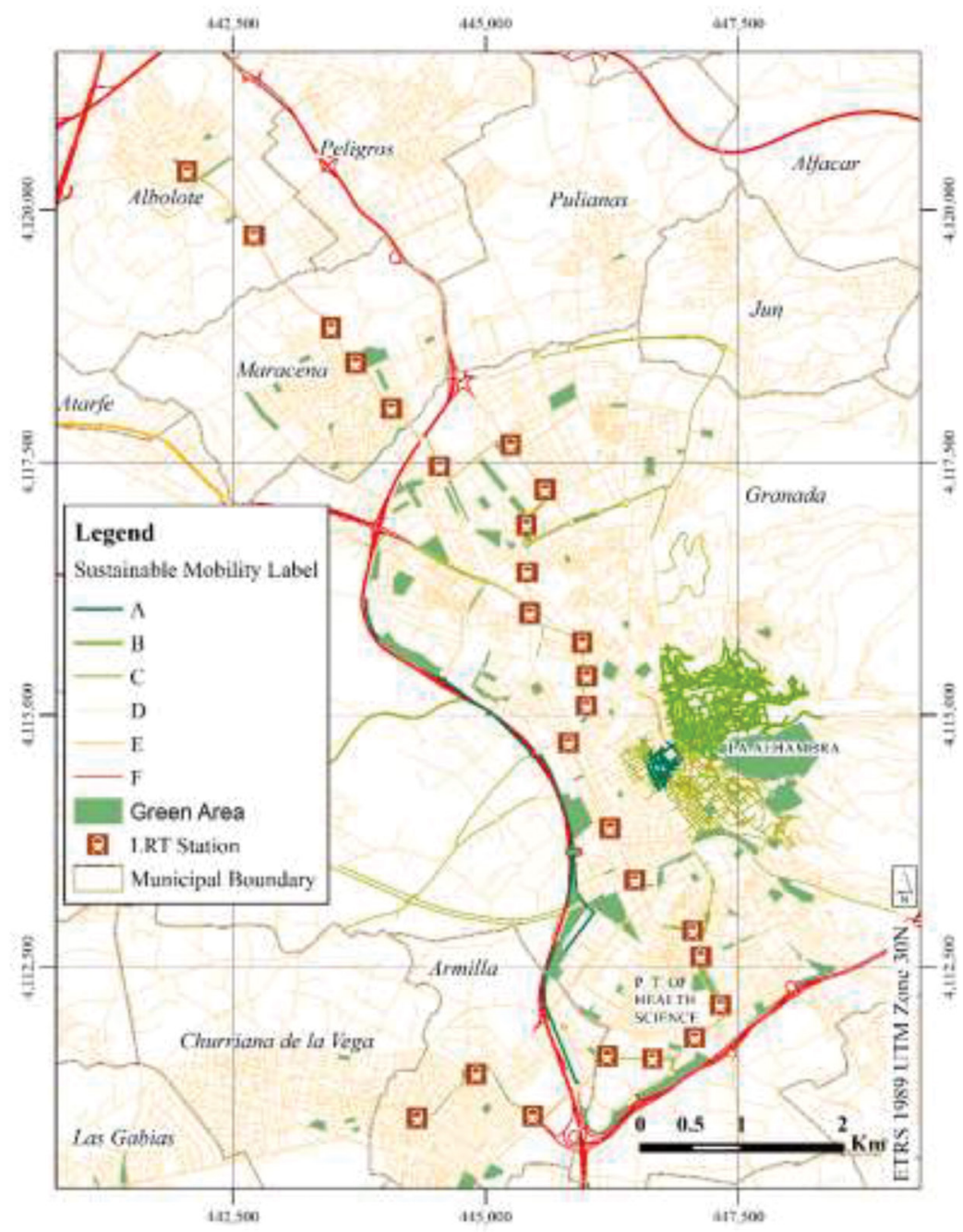

Figure 2: Sustainable mobility levels in Granada's metropolitan area (Source: Own research). 
Table 5: Sustainable mobility levels in Granada's metropolitan area (Source: Own research).

\begin{tabular}{|c|c|c|c|c|}
\hline $\begin{array}{l}\text { Sustainable mobility } \\
\text { level }\end{array}$ & Pre-COVID-19 [m] & $\%$ & Post-COVID-19 [m] & $\%$ \\
\hline A & 11,754 & $0.74 \%$ & 11,754 & $0.74 \%$ \\
\hline B & 38,048 & $2.41 \%$ & 38,048 & $2.41 \%$ \\
\hline $\mathrm{C}$ & 65,529 & $4.15 \%$ & 115,536 & $7.32 \%$ \\
\hline $\mathrm{D}$ & $1,265,820$ & $80.18 \%$ & $1,215,813$ & $77.01 \%$ \\
\hline $\mathrm{E}$ & 6,756 & $0.43 \%$ & 6,756 & $0.43 \%$ \\
\hline $\mathrm{F}$ & 190,856 & $12.09 \%$ & 190,856 & $12.09 \%$ \\
\hline Total & $1,578,763$ & $100 \%$ & $1,578,763$ & $100 \%$ \\
\hline
\end{tabular}

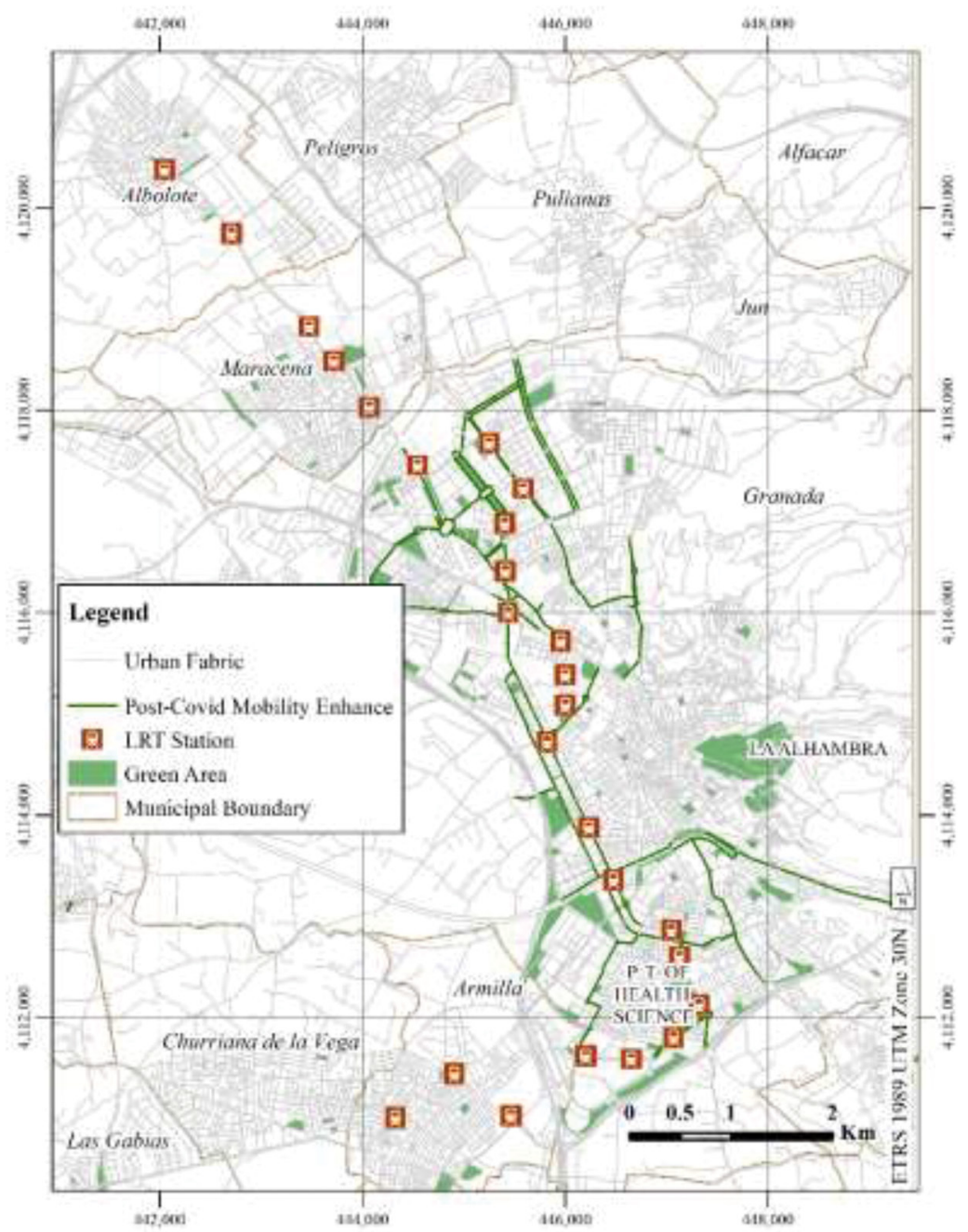

Figure 3: Post-COVID-19 mobility enhancement in Granada's urban area (Source: Adapted from Granada's Municipality Office of Integral Mobility Management). 
indirectly increasing the quality of their urban space. However, these changes have been minimal (only 3\%) with respect to the metropolitan streets (Table 5 and Fig. 3) and, in some cities, such as London, they have been subsequently reversed due to legal challenges [59].

\section{CONCLUSIONS}

Urban spaces and mobility systems are intrinsically related to one another. Their interactions are indisputable, as are their respective links to urban quality and sustainability. The relevant incidence of high-quality public transport systems promoting urbanity, urban sustainability, image and vitality in cities has also been demonstrated. With respect to its characteristics and its full compatibility with high-quality urban areas (according to sustainability dimensions), LRT can be considered as the superior public transit mode, enhancing the human orientation of cities, and creating a more positive environment.

The LRT in the metropolitan area of Granada is a good example of the positive synergies between urban space quality and sustainable public transportation. However, some potential opportunities for the integration of transport infrastructure with urban planning and land-use were not considered. A marked increase in the space given to pedestrians and bicycles was created along its corridor, although the majority of the metropolitan street systems are of a conventional urban design (97\%). The higher quality areas are limited to only a few completely pedestrianized central areas and the rest of its corridor consists of motorized mobilityoriented areas, with high traffic presence, resulting in reduced urban quality along the route.

The sustainability of the metropolitan transport system has improved, but only a limited part of the metropolitan urban space has been reshaped and revitalized, despite its traditional cross section design. Consequently, it gives high priority to motorized vehicular access and a reduced sustainable mobility level, and this is not enough to solve the serious environmental problems resulting from its high pollution effect.

A space analysis has been developed to explain the correspondence between the models of urban spaces and sustainable mobility levels. A grading of these mobility levels was proposed in order to evaluate the quality of the urban space. The assessment was made by means of the proportion of existing sustainable mobility areas in the cross sections of the streets in question. The urban space was classified from A to F. Section A indicates plenty of sustainable mobility areas, and therefore urban spaces of high-quality, whilst section $\mathrm{F}$ is designated as being fully motorized vehicle-oriented areas with no pedestrian or bicycle access.

The COVID-19 pandemic has forced various changes in order to facilitate social distancing, increasing urban space for sustainable mobility modes. These adaptations carried out in the Granada urban area have had a modest impact on the sustainable mobility areas. Streets designated as A-B-C levels were $7.93 \%$ pre-COVID-19 and increased to $10.47 \%$ postCOVID-19, just 3\%. This reveals the need for promoting improvements in urban spaces and sustainable mobility at a metropolitan scale since the LRT alone does not create a big enough change without the addition of other urban and mobility integrated measures.

\section{REFERENCES}

[1] Vuchic, V.R., Transportation for Livable Cities, Routledge: London and New York, 2017.

[2] Higgins, C., Ferguson, M., \& Kanaroglou, P., Light rail and land use change: rail transit's role in reshaping and revitalizing cities. Journal of Public Transportation, 17(2), pp. 93-112, 2014. http://doi.org/10.5038/2375-0901.17.2.5 
[3] Kasraian, D., Maat, K., Stead D. \& van Wee B., Long-term impacts of transport infrastructure networks on land-use change: an international review of empirical studies, Transport Reviews, 36(6), pp. 772-792, 2016. https://doi.org/10.1080/0144164 7.2016.1168887

[4] Chen, C.L., Transport and place-making: a long view. In Sir Peter Hall: Pioneer in Regional Planning, Transport and Urban Geography. Springer: Cham. pp. 37-58, 2016.

[5] Grindlay, A.L., Ochoa-Covarrubias, G. \& Lizarraga, C., Urban mobility and quality of public spaces: the case of Granada, Spain, WIT Transactions on the Built Environment, Vol. 200, WIT Press, 2020, ISSN 1746-4498. https://doi.org/10.2495/UT200041

[6] Grindlay, A.L., Molero, E., Miralles-Guash, C., \& Lizarraga, C., Environmental impacts of everyday mobility in Andalusia (Spain): towards a sustainable scenario? WIT Transactions on Ecology and the Environment, vol. 194, WIT Press: Southampton and Boston, pp. 373-384, 2015. http://dx.doi.org/10.2495/SC150331

[7] Buchanan, C., Traffic in Towns. Penguin Books: Harmondsworth, 1964.

[8] Parfect, M. \& Power, G., Planning for Urban Quality: Urban Design in Towns and Cities. Routledge: London, 1997.

[9] Banister, D., The sustainable mobility paradigm. Transport Policy, 15(2), pp. 73-80, 2008. https://doi.org/10.1016/j.tranpol.2007.10.005

[10] Currie, G. \& De Gruyter, C., Exploring links between the sustainability performance of urban public transport and land use in international cities. Journal of Transport and Land Use, 11(1), pp. 325-342, 2018. http://dx.doi.org/10.5198/jtlu.2018.957

[11] Miller, P., de Barros, A.G., Kattan, L. \& Wirasinghe, S.C., Public transportation and sustainability: a review. KSCE Journal of Civil Engineering, 20(3), pp. 1076-1083, 2016. https://doi.org/10.1007/s12205-016-0705-0

[12] Kumari, P. \& Toshniwal, D., Impact of lockdown on air quality over major cities across the globe during COVID-19 pandemic. Urban Climate, 34, 100719, 2020. https://doi. org/10.1016/j.uclim.2020.100719

[13] Orro, A, Novales, M. Monteagudo, Á. Pérez-López, J-B. \& Bugarín, M.R., Impact on city bus transit services of the COVID-19 lockdown and return to the new normal: the case of a Coruña (Spain). Sustainability, 12(17), 7206, 2020. http://dx.doi.org/10.3390/ su12177206

[14] Goodwin, P. \& Curtis, C., Sustainable transport: looking back - looking forward. Handbook of Sustainable Transport ed. C. Curtis, Edward Elgar Pub.: Cheltenham, pp. 434-446, 2020. https://doi.org/10.4337/9781789900477.00057

[15] Williams, K., Spatial planning, urban form and sustainable transport: an introduction. Spatial Planning, Urban Form and Sustainable Transport, ed. K. Williams, Ahsgate: Farnahm, pp. 1-13, 2005.

[16] Bertolini, L., Planning the Mobile Metropolis: Transport for People, Places and the Planet. Macmillan International Higher Education: London, 2017.

[17] EU, LEIPZIG CHARTER on Sustainable European Cities, Online, available at http:// ec.europa.eu/regional_policy/archive/themes/urban/leipzig_charter.pdf, 2007 (accessed 20 January 2020).

[18] Commission of the European Communities, Green Paper. Towards a new culture for urban mobility. Brussels, 25.9.2007COM 551 Final. Online, available at https://eurlex.europa.eu/legal-content/EN/TXT/PDF/?uri=CELEX:52007DC0551\&from=EN (accessed 20 January 2020). 
[19] Sanz Alduan, A., Urbanismo y Movilidad Sostenible. Guía para la construcción de ciudades siguiendo criterios de movilidad sostenible. NASURSA Navarra de Suelo Residencial, S.A., Online, available at https://ind01.safelinks.protection.outlook. com/?url=http\%3A\%2F\%2Fwww.upv.es\%2Fcontenidos\%2FCAMUNISO $\% 2$ Finfo \%2FU0538399.pdf\&amp;data=04\% 7C01\%7Coupjournals.t1\%40integra.co.in\%7C aac9d24b211b4b60175a08d992225551\%7C70e2bc386b4b43a19821a49c0a744f3 d\%7C0\%7C0\%7C637701498427956871\%7CUnknown\%7CTWFpbGZsb3d8eyJWIj oiMC4wLjAwMDAiLCJQIjoiV2luMzIiLCJBTiI6Ik1haWwiLCJXVCI6Mn0\%3D\%7 C1000\&amp;sdata=94hrbIU5qxZ1WMJhITTpnf2jY\%2BqMGD\%2FuDVayokBUgIU \%3D\&amp;reserved=0, 2010 (accessed 20 January 2012).

[20] Institute for Transportation and Development Policy (ITDP), Our Cities Ourselves: Principles for Transport in Urban Life, Online, https://www.itdp.org/2011/08/29/ourcities-ourselves-principles-for-transport-in-urban-life/, 2011 (accessed 20 January 2012).

[21] Gehl, J., Cities for People, Island Press: Washington, 2010.

[22] ARUP, Cities Alive. Towards a walking world, online, available at https://www.arup. com/perspectives/publications/research/section/cities-alive-towards-a-walking-world, 2016 (accessed 2 February 2018).

[23] Bendiks, S. \& Degros, A., Traffic Space is Public Space. A handbookfor transformation. Park Books: Zurich, 2019.

[24] Scudellari, J., Staricco, L. \& Vitale Brovarone, E., Implementing the Supermanzana approach in Barcelona. Critical issues at local and urban level. Journal of Urban Design, 25(6), pp. 675-696, 2020. https://doi.org/10.1080/13574809.2019.1625706

[25] Moreno, C., Allam, Z., Chabaud, D., Gall, C., \& Pratlong, F., Introducing the " 15 -minute city": sustainability, resilience and place identity in future post-pandemic cities. Smart Cities, 4(1), pp. 93-111, 2021. https://doi.org/10.3390/smartcities4010006

[26] Ministerio de Fomento. Guía Metodológica para los Sistemas de Auditoría, Certificación o Acreditación de la Calidad y Sostenibilidad del Medio Urbano. Centro de Publicaciones. Secretaría General Técnica, 2012.

[27] Mouratidis, K., \& Poortinga, W., Built environment, urban vitality and social cohesion: do vibrant neighborhoods foster strong communities? Landscape and Urban Planning, 204, pp. 103951, 2020. https://doi.org/10.1016/j.landurbplan.2020.103951

[28] Martí P., Nolasco-Cirugeda, A. \& Serrano-Estrada, L., Assessment tools for urban sustainability policies in Spanish Mediterranean tourist areas. Land Use Policy, 67, pp. 625-639, 2017. https://doi.org/10.1016/j.landusepol.2017.06.015

[29] Ferbrache, F., \& Knowles, R.D., City boosterism and place-making with light rail transit: a critical review of light rail impacts on city image and quality. Geoforum, 80 , pp. 103-113, 2017. http://dx.doi.org/10.1016/j.geoforum.2017.01.013

[30] Mc Leod, S., Scheurer, J. \& Curtis, C., Urban public transport: planning principles and emerging practice. Journal of Planning Literature, 32 (3), pp. 1-17, 2017. https://doi. org $/ 10.1177 / 0885412217693570$

[31] Rădulescu, V., Străinescu, I., Moroianu, L., Tudor, E., Gheorghe, S. \& Goia, C., The Urban Electrical Vehicles as the Solution for Public Transportation in the Cities of Romania. WIT Transactions on the Built Environment, Vol. 116, WIT Press: Southampton and Boston, pp. 449-458. 2011. https://doi.org/10.2495/UT110381

[32] Jacobs, J., The Death and Life of Great American Cities. Vintage Books: New York, 1961. 
[33] Chapman, D.W. \& Larkham, P.J., Urban design, urban quality, and the quality of life: reviewing the department of the environment's urban design campaign. Journal of Urban Design, 4(2), pp. 211-232, 1999. https://doi.org/10.1080/13574809908724447

[34] Sholihah, A.B., Overview of urban quality indicators: towards a sustainable and sophisticated urban life in Indonesia. Proceeding 4th International Conference on Sustainable Built and Environment (ICSBE), pp. 495-503, 2016.

[35] Ewing, R. \& Handy, S., Measuring the unmeasurable: urban design qualities related to walkability. Journal of Urban Design, 14(1), pp. 65-84, 2009. http://dx.doi. org/10.1080/13574800802451155

[36] Miller, H.J., Witlox, F. \& Tribby, C.P., Developing context-sensitive livability indicators for transportation planning: a measurement framework. Journal of Transport Geography, 26, pp. 51-64, 2013. https://doi.org/10.1016/j.jtrangeo.2012.08.007

[37] Dur, F., Yigitcanlar, T. \& Bunker, J., A Spatial-Indexing model for measuring neighbourhood-level land-use and transport integration. Environment and Planning B: Planning and Design, 41(5), pp. 792-812, 2014. https://doi.org/10.1068/b39028

[38] Garau, C. \& Pavan V.M., Evaluating urban quality: indicators and assessment tools for smart sustainable cities. Sustainability, 10(3), 575, 2018. https://doi.org/10.3390/ su10030575

[39] Montgomery, J., Making a city: urbanity, vitality and urban design. Journal of Urban Design, 3(1), pp. 93-116, 1998. http://dx.doi.org/10.1080/13574809808724418

[40] Delclòs-Alió, X. \& Miralles-Guasch, C., Looking at Barcelona through Jane Jacobs's eyes: mapping the basic conditions for urban vitality in a Mediterranean conurbation. Land Use Policy, 75, pp. 505-517, 2018. https://doi.org/10.1016/j.landusepol.2018.04.026

[41] Litman, T., Sustainability and Livability: Summary of Definitions, Goals, Objectives and Performance Indicators. Victoria Transport Policy Institute V8V 3R7, Online, available at www.vtpi.org/sus_liv.pdf, 2011 (accessed 20 January 2012).

[42] UN-Habitat, New Urban Agenda, ONU: Quito, Online, available at https://habitat3.org/ wp-content/uploads/NUA-English.pdf, 2017 (accessed 2 February 2018).

[43] Talen, E., Pedestrian Access as a Measure of Urban Quality. Planning Practice \& Research, 17(3), pp. 257-278, 2002. https://doi.org/10.1080/026974502200005634

[44] Talavera-Garcia, R. \& Soria-Lara, J.A., Q-PLOS, Developing an Alternative Walking Index. A Method Based on Urban Design Quality. Cities 45, pp.7-17, 2015. https://doi. org/10.1016/j.cities.2015.03.003

[45] Fleming, S., Cycle Space: Architecture \& Urban Design in the Age of the Bicycle. NAi010 Publishers: Rotterdam, 2012.

[46] Oleas Mogollón, D. \& Albornoz Barriga, M., La Bicicleta y la Transformación del Espacio Público en Quito (2003-2014). Letras Verdes, 19, pp. 24-44, 2016. https://doi. org/10.17141/letrasverdes.19.2016.1817

[47] Pflieger, G., Kaufmann, V., Pattaroni, L., \& Jemelin, C., How does urban public transport change cities? Correlations between past and present transport and urban planning policies. Urban Studies, 46(7), pp. 1421-1437, 2009. https://doi. org/10.1177/0042098009104572

[48] Chen, C.-L., Wider impacts of rail-based transport investment on urban and economic development - literature review. EU INTERREG 4B SINTROPHER project London, Bartlett School of Planning, University College London, 2014.

[49] Shyr, O.F., Andersson, D.E., Cheng, Y.H., \& Hsiao, Y.H., What explains rapid transit use? Evidence from 97 urbanized areas. Transportation Research Part A: Policy and Practice, 100, pp. 162-169, 2017. http://dx.doi.org/10.1016/j.tra.2017.04.019 
[50] Boquet, Y., The renaissance of tramways and urban redevelopment in France, Miscellanea Geographica, 21(1), pp. 5-18, 2017. https://doi.org/10.1515/mgrsd-2017-0005

[51] Larsson, A., Integrating land use and transport: understanding the dynamics of proximity. Handbook of Sustainable Transport, ed. C. Curtis, Edward Elgar Pub.: Cheltenham, pp. 289-297, 2020. https://doi.org/10.4337/9781789900477.00042

[52] Jones, P., Boujenko, N. \& Marshall, S., Link \& Place: A Guide to Street Planning and Design. Landor Press: London, 2007.

[53] Transportation Research Board, Highway Capacity Manual 2010 (HCM 2010), National Academy of Sciences: Washington, DC, 2010.

[54] Sánchez, E. \& Sevillano, E.G., 15 million Spaniards are breathing air the EU considers polluted. More than half of Spain is wreathed in air containing excessive levels of particulate matter, nitrogen dioxide and ozone, El País, Madrid, 07 December 2018. Online, available at https:/english.elpais.com/elpais/2018/12/05/ inenglish/1544008632_514634.html (accessed 14 December 2018).

[55] Lizárraga, C. \& Grindlay, A.L., Hacia un modelo de movilidad urbana sostenible en Andalucía. Actualidad, 65. Centro de Estudios Andaluces: Sevilla. Online, available at https://centrodeestudiosandaluces.es/publicaciones/n-65-hacia-un-modelo-de-movilidadurbana-sostenible 2012.

[56] Gómez Ordóñez, J.L. et al., Informe sobre el Metro Ligero de Granada. Las oportunidades urbanísticas de la línea metropolitana N-S sobre el soterramiento del tramo central, Online, available at http://hdl.handle.net/10481/6559 2004.

[57] Ayuntamiento de Granada. Office of Integral Mobility Management Web Site, Granada, Spain, available at www.movilidadgranada.com/zon_index.php (accessed 1 December 2020).

[58] Ayuntamiento de Granada, Plan de Movilidad Urbana Sostenible de Granada, online, available at http://www.movilidadgranada.com/pmus_index.php, 2012 (accessed 1 December 2012).

[59] O’Sullivan, F., Court Battles Threaten London's Pandemic-Era Car Restrictions. Bloomberg CityLab, 29 January 2021. Online, available at https://www.bloomberg.com/news/ articles/2021-01-29/lawsuits-challenge-london-s-car-restrictions?cmpid=BBD020421 _CITYLAB\&utm_medium=email\&utm_source=newsletter\&utm_term=210204\&utm_ campaign=citylabdaily (accessed 12 February 2021). 